\title{
Changes in Soil Health with Remediation of Petroleum Hydrocarbon Contaminated Soils Using Two Different Remediation Technologies
}

\author{
Sang Hwan Lee ${ }^{1, *}$, Jung Hyun Lee ${ }^{1}$, Woo Chul Jung ${ }^{1}$, Misun Park ${ }^{1}$, Min Suk Kim ${ }^{2}{ }^{\mathbb{D}}$, \\ Seung Jae Lee ${ }^{3(1)}$ and Hyun Park ${ }^{3, *} *$ (D) \\ 1 Technical Research Institute, Mine Reclamation Corporation, Wonju 26464, Korea; \\ 4frontier@mireco.or.kr (J.H.L.); woochul@mireco.or.kr (W.C.J.); mspark@mireco.or.kr (M.P.) \\ 2 O-Jeong Resilience Institute, Korea University, Seoul 02841, Korea; adoniss86@korea.ac.kr \\ 3 Collage of Life Sciences and Biotechnology, Korea University, Seoul 02841, Korea; skullcap@korea.ac.kr \\ * Correspondence: soillsf@mireco.or.kr (S.H.L.); hpark@korea.ac.kr (H.P.); \\ Tel.: +82-33-902-6740 (S.-H.L.); +82-2-3290-3051 (H.P.)
}

Received: 1 November 2020; Accepted: 1 December 2020; Published: 3 December 2020

\begin{abstract}
For sustainable soil management, there is an increasing demand for soil quality, resilience, and health assessment. After remediation of petroleum hydrocarbon (PHC)-contaminated soils, changes in the physicochemical and ecological characteristics of the soil were investigated. Two kinds of remediation technologies were applied to contaminated soils: land farming (LF) and high temperature thermal desorption (HTTD). As a result of total petroleum hydrocarbons (TPH), PHC-contaminated soils were efficiently remediated by LF and HTTD. The soil health could not be completely recovered after the removal of pollutants due to adverse changes in the soil properties, especially in soil enzyme activities. Therefore, monitoring is necessary for accurate estimation of soil ecotoxicity and effective remediation, and additional soil management, such as fertilizer application or organic amendments, is needed to restore soil heath. In the case of HTTD, soil ecological properties are severely changed during the remediation process. The decision to reuse or recycle remediated soils should reflect changes in soil quality. HTTD is a harsh remediation method that results in deterioration of soil fertility and ecological functions. Alternatives, such as low-temperature thermal desorption or additional soil management using fertilizer or organic amendments, for example, are needed.
\end{abstract}

Keywords: bioremediation; landfarming; monitoring; soil health; thermal desorption

\section{Introduction}

Petroleum hydrocarbons (PHCs) are common contaminants in soil and groundwater resulting from past and current industrial activities [1,2]. Of greatest concern with respect to contamination by hydrocarbons is their mutagenic, carcinogenic, and toxic characteristics [3]. Therefore, a variety of remediation technologies have been developed to mitigate the hazards of these pollutants in the environment in consideration of human health arising from pollutants $[4,5]$.

Remediation treatment methods and techniques play a vital role in the cleaning of contaminated environments, in terms of containment, removal, reclamation, and restoration. The remediation approach should be chosen according to the characteristics of the contaminated site, including the nature and composition of pollutants, as well as the physical, chemical, and biological conditions of the affected environment. With increasing calls to reduce environmental pollutions, the primary focus of environmental scientists is presently the adoption of risk-based management approaches to remediate 
contaminated environments to reduce health risks or damage to the affected environment. In most cases, authorities prioritize the most urgent cases, and those for which remediation is less difficult [6].

Historically, remediation of contaminated sites focused solely on contaminant removal; other environmental, social, and economic considerations tended to remain unaddressed. These unaddressed concerns promoted the rise of the "sustainable remediation" concept. Sustainable remediation is a cost-reducing measure that also has long-term implications [7].

The level of pollutants in the soil can be sufficiently lowered by soil remediation, but in the process, the changes of soil characteristics and serious damage to soil health may not restore soil function [8]. Soil is an irreplaceable natural resource [9], and interest for the reuse of contaminated soil is increasing. To facilitate the reuse of remediated soil, it is also important to increase the remediation efficiency and minimizing disturbance in soil characteristics related to soil quality and health. However, studies have primarily focused on the development of remediation techniques that can be applied to specific contaminants or sites, as well as those that can increase remediation efficiency or reduce the remediation time [10-12].

Comprehensive monitoring is crucial for successful remediation, and ecotoxicity monitoring in particular is essential for evaluating the progress of remediation and soil health, in addition to the removal of oil contaminations [13]. A reduction in the soil pollutant concentration alone does not always indicate decreased ecotoxicity [14]. To assess the results of remediation of contaminated soils, in addition to measuring the remaining pollutant content in soil or its transformation into non-toxic end-products, it is essential to determine the extent to which soil functions have been affected both during and after the process [15].

A lack of consideration of the potential formation of toxic intermediate metabolites and changes in contaminant bioavailability may pose an ecological risk. Therefore, the use of chemical analyses in combination with ecotoxicity assays is recommended when evaluating the ecological risks associated with PHC contamination. Extensive ecotoxicity monitoring and bioindicator screening, as well as final evaluation of remediation efficiency, are very important for remediation process control and environmental safety.

The aims of this study were (1) to use various ecological assays to evaluate changes in soil health, and (2) to encourage the use of bioassays in combination with chemical data generated by soil quality assessments for sustainable remediation.

\section{Materials and Methods}

\subsection{Soils}

Two types of oil-contaminated soil were used in this study: diesel-contaminated soil treated by landfarming (LF), and bunker C-contaminated soil treated by high-temperature thermal desorption (HTTD). Non-contaminated soil (NCS) was collected from around each site for ecological assessment in terms of microbial community, soil enzyme activity, phytotoxicity, and earthworm toxicity. Diesel-contaminated soil was supplied as fertilizer for hydrocarbon-degrading bacteria. Land farming is one of the biological restoration methods of oil contaminated soil, and oil concentration is reduced by utilizing microorganisms capable of decomposing oil; the soil was tilled every 2 weeks and irrigated with water on a weekly basis over 45 days. The HTTD process involved heating the soil to $600{ }^{\circ} \mathrm{C}$ for $10 \mathrm{~min}$ with heated air generated from a regenerative thermal oxidizer.

\subsection{Analytical Methods}

\subsubsection{Phsicochemical Properties of Soils}

The soils were analyzed for various chemical and physical properties: $\mathrm{pH}$ and EC by glass electrode method (1:5 water suspension); total $\mathrm{N}$ by the Kjeldhal method [16]; organic matter by the Turyn method [17]; cation exchange capacity (CEC) by the $\mathrm{NH}_{4}{ }^{+}$saturation and distillation 
method [18]; and available P by the Bray method [19]. Wet sieving with single sieve method was used for determination aggregate stability [20].

To determine the total petroleum hydrocarbons (TPHs) in soil, soil samples were extracted with dichloromethane. The extract was concentrated under a stream of nitrogen and dried over anhydrous sodium sulphate, and TPHs were analyzed by a gas chromatograph with a flame ionization detector (GC-FID; 6890; Agilent Technologies, Santa Clara, CA, USA). Chromatography was performed on an SGE BPX-5 fused-silica capillary column $(15 \mathrm{~m} \times 0.32 \mathrm{~mm}$ i.d.) coated with HP-5 $(0.10-\mu \mathrm{m}$ film thickness). Helium was used as the carrier gas at $2.5 \mathrm{~mL} \mathrm{~min}^{-1}$. The FID temperature was maintained at $300{ }^{\circ} \mathrm{C}$. Splitless injection was applied with a sample volume of $1 \mu \mathrm{L}$. The oven temperature was increased from $50{ }^{\circ} \mathrm{C}$ to $300{ }^{\circ} \mathrm{C}$ at a gradient of $25^{\circ} \mathrm{C} \mathrm{min}-1$, then held at $300^{\circ} \mathrm{C}$ for $5 \mathrm{~min}$.

\subsubsection{Ecological Assessment}

Quantification of the total bacterial cells in samples was performed by tuf qPCR. A quantitative tuf qPCR kit for bacteria (Takara Bio, Shiga, Japan) with SYBR Green technology was used. The reaction was performed with $5 \mu \mathrm{L}$ of template DNA in a total volume of $25 \mu \mathrm{L}$, according to the manufacturer's protocol (Takara Bio). A positive tuf gene standard stock solution, provided with the kit, was used to generate a linear standard curve by plotting the cycle threshold values, which allowed the results to be expressed in copies per gram (equivalent to colony forming units per gram).

Total metagenomic DNA was extracted and purified using the DNeasy PowerSoil Pro Kit (Qiagen, Germantown, MA, USA) according to the manufacturer's instructions. To make a 16S amplicon with Pacbio, genomic DNA was amplified using KAPA HiFi HotStart Ready Mix PCR kit (Cat No. KK2660) according to the protocol provided by Pacific Biosciences. SMRT LR cells (Pacific Biosciences) and Sequel Sequencing Kit v3.0 were installed on instrument, and then proceeded sequencing on $20 \mathrm{~h}$. High Fidelity (HiFi) reads of $16 \mathrm{~S}$ rRNA genes were generated by SMRT ${ }^{\circledR}$ Link software with circular consensus sequences (CCS) mode. Microbial community analysis of demultiplexed 16S CCS reads was performed with Quantitative Insights into Microbial Ecology 2 (QIIME2; https://qiime2.org/). Taxonomic profiling of chimera removed OTUs was performed with Genome Taxonomy Database (GTDB; https://gtdb.ecogenomic.org/).

Five soil enzyme activities were evaluated: dehydrogenase activity was determined with the method of Casida et al. [21]; $\beta$-glucosidase activity was determined by the method of Eivazi and Tabatabai [22]; alkaline phosphomonoesterase was determined by the method of Eivazi and Tabatabai [23]; urease activity was determined with the method of Kandeler [24]; and arylsulfatase was determined by the method of Tabatabai and Bremner [25].

A plant germination and shoot growth experiment was also performed. Lettuce (Lactuca sativa L.) was grown from seed in plastic filled with noncontaminated background soil, contaminated soil, or remediated soil. The experiment was conducted under controlled greenhouse conditions $\left(15-25^{\circ} \mathrm{C}\right.$, $60-70 \%$ relative humidity) with daily watering. After 14 days, the number of germinated seeds in each soil sample was counted and root lengths were measured. The 14 day period was selected for acute toxicity test according to Organization for Economic Cooperation and Development (OECD) guidelines [26].

The test species, Eisenia fetida, was chosen for its regular use in toxicity testing and its availability. Before the onset of the experiments, the soil samples were wetted to $60 \%$ of the WHC (water holding capacity). A total of 10 earthworms of equal size were added to soils and incubated. After 14 days of incubation, earthworm survival rate and body weights of individual earthworms were measured. The 14 day period was selected for acute toxicity test according to OECD guidelines [27]. All experiments were performed in triplicate.

\subsection{Data Analysis}

All values obtained for the chemical and biological analyses of soil are the means of three replicates. The means were compared using least significant differences calculated at a significance level of $a=0.05$ 
using SAS software (SAS Institute, 1989). Principal component analysis (PCA) was conducted using CANOCO for Windows and an ordination diagram was drawn to analyze the physical, chemical, and ecological soil properties.

\section{Results}

\subsection{Changes in Physico-Chemical Properties of Soils}

The changes in soil physicochemical properties (before vs. after treatment) are shown in Table 1 . Overall, $97 \%$ of the diesel was degraded by LF treatment, and bunker C was completely removed by HTTD treatment. In the LF-treated soil, the physicochemical properties that changed significantly during the remediation processes were organic matter (OM), total Kjeldahl nitrogen (TKN), available phosphorus, and aggregation stability. Most soil physicochemical properties improved.

Table 1. Changes of soil physicochemical properties *.

\begin{tabular}{ccccc}
\hline \multirow{2}{*}{ Parameter } & \multicolumn{2}{c}{ LF $^{\mathbf{1}}$} & \multicolumn{2}{c}{ HTTD $^{2}$} \\
\cline { 2 - 5 } & Before & After & Before & After \\
\hline $\mathrm{pH}$ & $8.53 \pm 0.35 \mathrm{a}$ & $6.95 \pm 0.08 \mathrm{~b}$ & $9.75 \pm 0.07 \mathrm{a}$ & $9.43 \pm 0.03 \mathrm{~b}$ \\
$\mathrm{EC}$ & $0.17 \pm 0.05 \mathrm{~b}$ & $0.45 \pm 0.04 \mathrm{a}$ & $3.84 \pm 0.14 \mathrm{a}$ & $3.89 \pm 0.00 \mathrm{a}$ \\
$\mathrm{OM}^{3}$ & $0.57 \pm 0.18 \mathrm{~b}$ & $1.04 \pm 0.09 \mathrm{a}$ & $1.29 \pm 0.06 \mathrm{a}$ & $0.76 \pm 0.22 \mathrm{~b}$ \\
TKN $^{4}$ & $0.03 \pm 0.01 \mathrm{~b}$ & $0.09 \pm 0.01 \mathrm{a}$ & $0.04 \pm 0.00 \mathrm{a}$ & $0.02 \pm 0.00 \mathrm{a}$ \\
$\mathrm{CEC}^{5}$ & $9.77 \pm 0.08 \mathrm{a}$ & $9.84 \pm 0.15 \mathrm{a}$ & $17.80 \pm 0.10 \mathrm{a}$ & $15.72 \pm 0.25 \mathrm{~b}$ \\
Av.P. $^{6}$ & $3.85 \pm 0.29 \mathrm{~b}$ & $12.40 \pm 0.48 \mathrm{a}$ & $0.76 \pm 0.06 \mathrm{a}$ & $0.73 \pm 0.04 \mathrm{a}$ \\
A.S. $^{7}$ & $10 \pm 2 \mathrm{~b}$ & $26 \pm 1 \mathrm{a}$ & $17 \pm 3 \mathrm{a}$ & $16 \pm 1.1 \mathrm{a}$ \\
TPH $^{8}$ & $5491 \pm 546 \mathrm{a}$ & $126 \pm 9 \mathrm{~b}$ & $528 \pm 89 \mathrm{a}$ & N.D. ${ }^{9} \mathrm{~b}$ \\
\hline
\end{tabular}

* Means and standard deviation $(n=3)$ followed by different letter within a row are significantly different $(p<0.05)$.

${ }^{1} \mathrm{LF}$, land farming; ${ }^{2} \mathrm{HTTD}$, high-temperature thermal desorption; ${ }^{3} \mathrm{OM}$, organic matter content $(\%) ;{ }^{4} \mathrm{TKN}$, total kjeldahl nitrogen (\%); ${ }^{5} \mathrm{CEC}$, cation exchange capacity $\left(\mathrm{cmol} \mathrm{kg}^{-1}\right) ;{ }^{6}$ Av.P., available phosphorus $\left(\mathrm{mg} \mathrm{kg}^{-1}\right)$;

${ }^{7}$ A.S., aggregation stability (\%); ${ }^{8} \mathrm{TPH}$, total petroleum hydrocarbon $\left(\mathrm{mg} \mathrm{kg}^{-1}\right) ;{ }^{9}$ N.D., not detected.

Unlike LF treatment, changes in soil properties were noticeable after thermal desorption, with significant decreases seen in $\mathrm{pH}, \mathrm{OM}$, and CEC. In contrast, EC, TKN, available phosphorus, and aggregation stability remained at very low levels (i.e., were largely unchanged).

\subsection{Changes in Ecological Properties of Soils}

\subsubsection{Microbial Community}

A total of 42 phyla, 96 classes, 205 orders, 332 families, and 736 bacterial genera were detected in all samples. Proteobacteria was the dominant phylum in all samples, followed by Acidobacteria, Bacteroidetes, and Actinobacteria (Figure 1).

As expected, NCS showed the highest diversity, with greater abundance of Gemmatimonadetes, Patescibacteria, Myxococcota, Planctomycetes, Verrucomicrobia, Chloroflexi, and Methylomirabilota compared to contaminated soils. Proteobacteria was the most abundant group, accounting for $83.2 \%$ of all phylotypes in diesel-contaminated soil and $86.2 \%$ in bunker C-contaminated soil. Gammaproteobacteria (74.0\%) and Alphaproteobacteria (9.2\%) were dominant in diesel-contaminated soil, while Gammaproteobacteria (83.3\%) dominated in bunker C-contaminated soil, with Alphaproteobacteria contributing only $2.9 \%$. Together, Bacteroidetes, Firmicutes, and Actinobacteria accounted for $24.7 \%$ of all bacteria in HTTD-treated soil. Notably, each taxon was dominated by one or three sub-groups, such as Betaproteobacteriales, Xanthomonadales, and Pseudomonadales in Gammaproteobacteria, Sphingomonadales in Alphaproteobacteria, Actinomycetales in Actinobacteria, and Chitinophagales in Bacteroidia in the LF-treated soil; and Betaproteobacteriales, Xanthomonadales, and Pseudomonadales in Gammaproteobacteria, and Rhodobacterales in Alphaproteobacteria in HTTD-treated soil. 

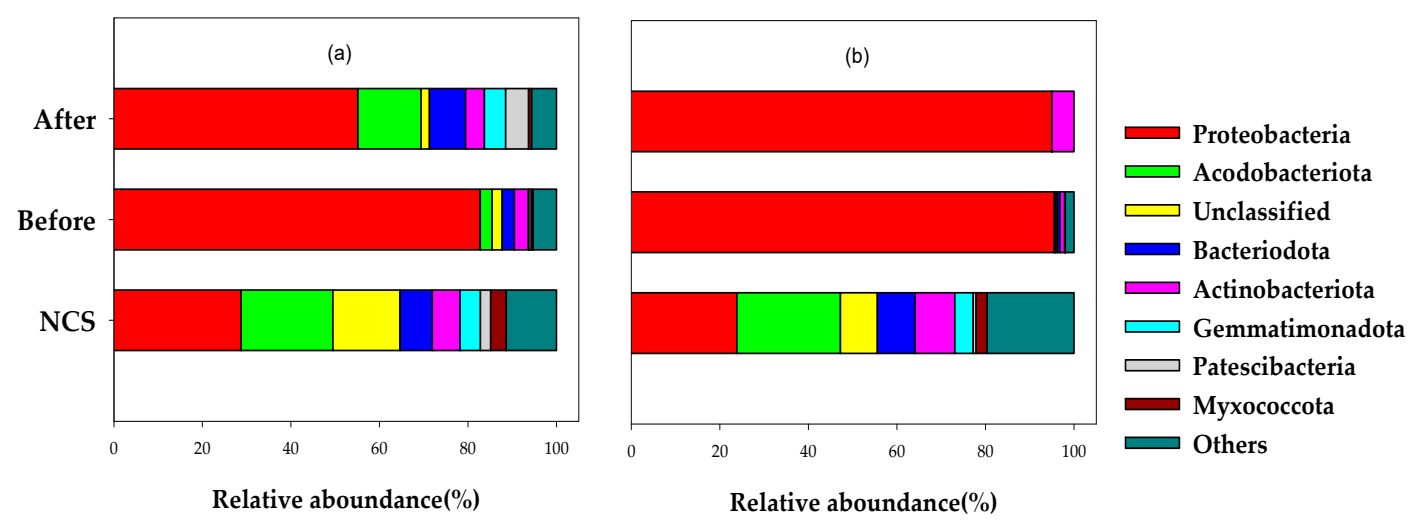

Figure 1. Comparison of the relative abundance of microbial consortium at the phylum level: (a) diesel-contaminated, landfarming soil and (b) bunker C contaminated soil (remediated via high temperature thermal desorption).

\subsubsection{Soil Enzyme Activities}

Figure 2 shows the enzyme activities in the soil samples, which differed significantly between LF-treated soil and HTTD-treated soil.

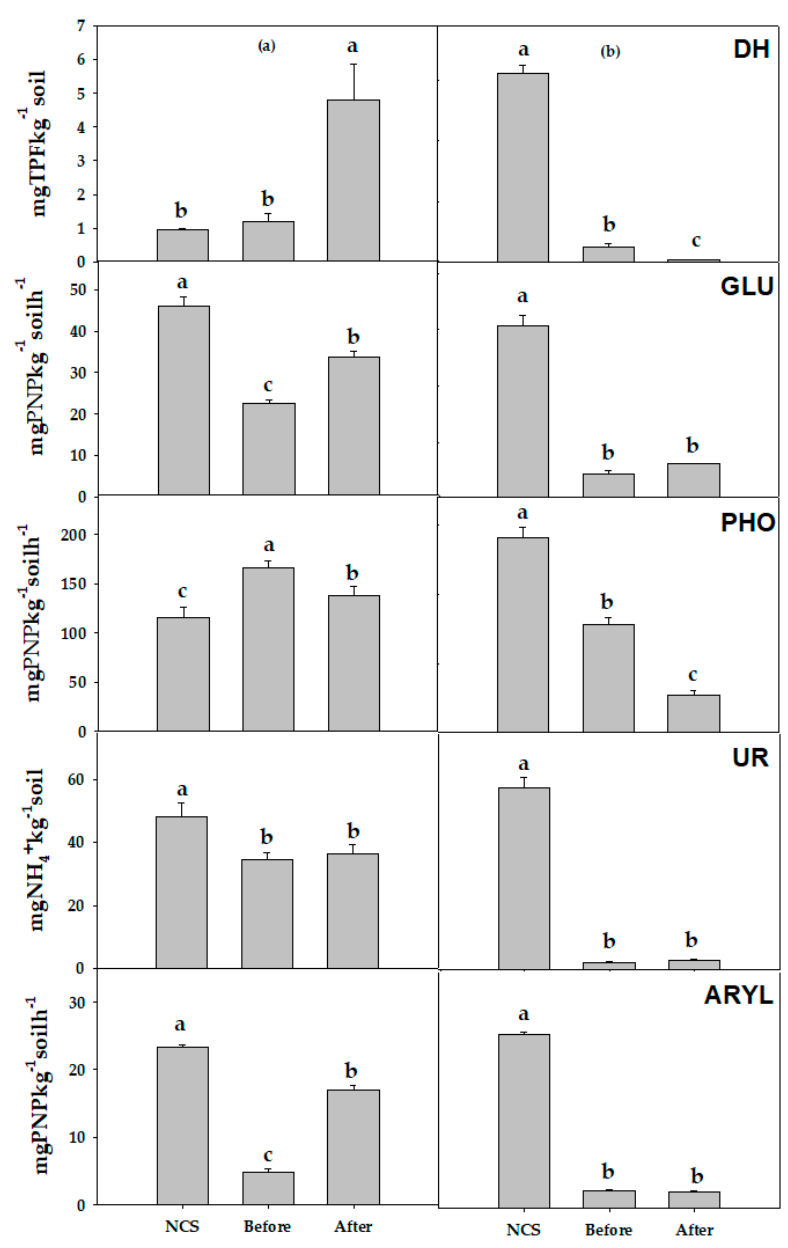

Figure 2. Changes in soil enzyme activities: (a) Diesel-contaminated LF-treated soil; (b) bunker C-contaminated HTTD-treated soil. From the top: dehydrogenase activity (DH), glucosidase activity (GLU), phosphatase activity (PHO), urease activity (UR), and arylsulfatase activity (ARYL). Different letters indicate significant differences at $\alpha=0.05$. 
In LF-treated soil, dehydrogenase, phosphatase, and arylsulfatase activities increased after treatment, while the activities of the remaining enzymes decreased. In HTTD-treated soil, the dehydrogenase and phosphatase activities were significantly reduced after treatment, but the glucosidase, urease, and arylsulfatase activities were almost unchanged. The activities of enzymes, both before and after HTTD treatment, were significantly lower than that of NCS.

\subsubsection{Plant Toxicity Assay}

The germination rate and growth data for lettuce (Lactuca sativa) are presented in Table 2. These parameters were evaluated 14 days after sowing, when the germination rate exceeded $70 \%$ in the NCS. On day 14, germination rate was $76.67 \pm 4.71 \%$ and $76.67 \pm 12.47 \%$ in NCS of LF and HTTD, respectively. The germination of lettuce failed on both contaminated soils, and was not completely recovered after treatment. Compared to NCS, LF- and HTTD-treated soils had germination rates of $60.8 \%$ and $47.8 \%$, respectively. While there was no difference in root growth length before versus after LF treatment, there was a significant increase after HTTD treatment.

Table 2. Results of plant toxicity assessment using lettuce.

\begin{tabular}{|c|c|c|c|c|c|c|}
\hline \multirow{2}{*}{ Phytotoxicity } & \multicolumn{3}{|c|}{$\mathrm{LF}^{1}$} & \multicolumn{3}{|c|}{ HTTD $^{2}$} \\
\hline & $\mathrm{NCS}^{3}$ & Before & After & NCS & Before & After \\
\hline $\begin{array}{l}\text { Germination } \\
(\%)\end{array}$ & $76.67 \pm 4.71 \mathrm{a}$ & $23.33 \pm 9.43 b$ & $46.67 \pm 9.43 b$ & $76.67 \pm 12.47 a$ & $60.00 \pm 8.16 a$ & $36.67 \pm 4.71 b$ \\
\hline $\begin{array}{l}\text { Root length } \\
\left(\mathrm{cm} \mathrm{plants}^{-1}\right)\end{array}$ & $3.76 \pm 0.15 a$ & $3.43 \pm 0.61 \mathrm{a}$ & $3.78 \pm 0.10 \mathrm{a}$ & $2.70 \pm 0.51 c$ & $3.93 \pm 0.53 b$ & $4.34 \pm 1.21 \mathrm{a}$ \\
\hline
\end{tabular}

\subsubsection{Earthworm Toxicity Assay}

The survival rate and body weights of earthworms (Esenia fetida) are presented in Table 3. They were determined 14 days after incubation. In the NCS, the survival rate was $96.67 \pm 5.77 \%$ and $100 \%$ on day 14 after LF and TD treatment, respectively. The earthworm survival rate was significantly reduced by diesel contamination and, while it was improved with LF treatment (86.67\%), it did not fully recover. Meanwhile, the survival rate decreased in the HTTD-treated soil to 77\%.

Table 3. Results of earthworm (Esenia fetida) toxicity assessment.

\begin{tabular}{|c|c|c|c|c|c|c|}
\hline \multirow{2}{*}{$\begin{array}{l}\text { Earthworm } \\
\text { Toxicity }\end{array}$} & \multicolumn{3}{|c|}{$\mathrm{LF}^{1}$} & \multicolumn{3}{|c|}{ HTTD $^{2}$} \\
\hline & $\mathrm{NCS}^{3}$ & Before & After & NCS & Before & After \\
\hline $\begin{array}{c}\text { Survival } \\
(\%)\end{array}$ & $96.67 \pm 5.77 a$ & $16.67 \pm 5.77 \mathrm{c}$ & $86.67 \pm 5.77 b$ & $100 \pm 0.00 \mathrm{a}$ & $96.67 \pm 5.77 a$ & $76.67 \pm 5.28 b$ \\
\hline $\begin{array}{c}\text { Body weight } \\
\left(\text { g earthworm }^{-1}\right)\end{array}$ & $0.22 \pm 0.01 \mathrm{a}$ & $0.16 \pm 0.01 b$ & $0.21 \pm 0.02 \mathrm{a}$ & $0.17 \pm 0.01 b$ & $0.15 \pm 0.02 c$ & $0.21 \pm 0.01 \mathrm{a}$ \\
\hline
\end{tabular}

The body weight of earthworms increased to the NCS level after LF treatment, while in HTTD-treated soil, the body weight exceeded the NCS level.

\section{Discussion}

To evaluate possible soil quality disturbances resulting from soil remediation processes, the physicochemical and ecological characteristics of soils were assessed. Diesel- and bunker C-contaminated soils can be successfully remediated with LF and HTTD treatments, respectively; however, soil properties are altered during remediation (Table 1). The changes in physicochemical 
properties resulting from remediation processes resulted in changes in ecological properties. First, there were significant changes in microbial community abundance. The abundance of Proteobacteria was reduced in LF-treated soil (the abundances of other consortium members increased) but increased in HTTD-treated soil (the abundances of other consortium members decreased) (Figure 1). It is unclear whether Proteobacteria are resistant to high temperatures, but the results for the LF treatment showed that they are resistant to oil components. The relative distribution ratio of Proteobacteria in contaminated soil tended to decrease with treatment time. Proteobacteria were reported to be dominant in petroleum-contaminated soils [28]. Soil microorganisms are resistant to even higher temperatures in some cases, surviving after heating up to $300-400{ }^{\circ} \mathrm{C}$ [29]. However, other studies reported declines in microorganisms at heating temperatures below $300{ }^{\circ} \mathrm{C}$ [30]. Pape et al. [31] reported that, at temperatures above $500{ }^{\circ} \mathrm{C}$, microbial activity may not recover without additional soil management, such as fertilizer application or organic amendments.

Increased dehydrogenase, glucosidase, and arylsulfatase activities following LF treatment were likely due to the decreased level of contaminants (Figure 2). Wang et al. [32] reported that dehydrogenase activity can be suppressed when the hydrocarbon concentration exceeds a threshold value of $\sim 1000 \mathrm{mg} \mathrm{kg}^{-1}$. The higher the concentration of low boiling point and/or unsaturated compounds, aromatics, and acids, the more toxic are hydrocarbons to microorganisms in the soil [33]. The increases in these enzyme activities after LF treatment can be attributed to biological degradation of toxic substances that inhibit microbial enzyme activity. The higher levels of phosphatase activity in diesel-contaminated soil are due to the hydrocarbons in the soil. When the soil contains more than $1000 \mathrm{mg} \mathrm{kg}^{-1}$ of residual hydrocarbons, phosphatase activity gradually increases [32]. Increased acid phosphatase activity may also facilitate plant and microbial growth by increasing the inorganic phosphorous concentration in soil. When the concentration of easily utilizable substrates decreases below a critical level, microorganisms shift towards the production of enzymes to regenerate nutrients from $\mathrm{OM}$, and vice-versa (i.e., when the hydrolysis products are sufficient to meet microbial demands, enzymatic production is suppressed). In HTTD-treated soil, the dehydrogenase and phosphatase activities were significantly reduced, which can be attributed to a reduction in the number of microorganisms and the variety of species. The number of total heterotrophic bacteria decreased from $10^{7}$ to $10^{3}$ in HTTD-treated soil (data not shown).

PHC pollution has negative effects on plant germination and growth [34]. The volatile fraction of diesel fuel has an inhibitory effect on seed germination [35]. Because the TPH concentration decreased and the volatile fraction of the TPHs was removed by both LF and HTTD, the germination rate increased but was still lower than that in NCS (Table 2). These results suggest that LF and HTTD have a positive effect on the germination and growth of lettuce by decreasing the TPH concentration in soil, but complete recovery of soil health in terms of plant germination and growth cannot be guaranteed. The complexity of PHC contaminants, along with the formation of pollutant intermediates, renders ecotoxicity monitoring and control difficult. Furthermore, these hazards cannot be identified by the human senses alone [36,37]. Therefore, monitoring is urgently required to promote accurate estimation of soil ecotoxicity strength and the effectiveness of bioremediation.

Earthworms, which are representative of soil macro fauna, are useful for monitoring soil health in both acute and sub-lethal ecotoxicity tests [38]. The increased survival rate and biomass of earthworms after LF treatment can be interpreted similarly to the increase in the germination rate of lettuce (Table 3). The reduction in light and volatile fractions resulted in an increase in the survival rate and body weight of the earthworms in this study. In this respect, E. fetida is an ideal earthworm species for assessing the level of hydrocarbon contamination [39].

PCA of the soil properties showed a clear change in the overall soil properties after HTTD (Figure 3). The results showed that overall soil health was improved after LF treatment. However, the ecological properties showed several differences compared to NCS, and soil ecological functions must be improved to achieve better soil quality. In the case of HTTD, the soil was remediated with thermal desorption, but the soil ecological properties were severely changed during the remediation process. HTTD is a 
harsh remediation method that results in deterioration of soil fertility and ecological soil functions; alternatives, such as low-temperature thermal desorption (LTTD), are needed. Ren et al. [40] reported that LTTD (typically operated at $100-350^{\circ} \mathrm{C}$ ) not only improves energy efficiency, but may also attenuate damage to soil; thus, LTTD has great potential to become a sustainable remediation technology.

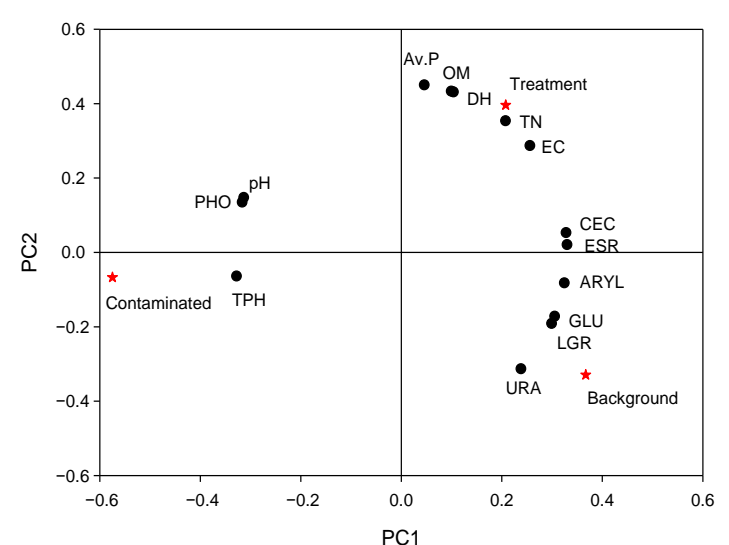

(a)

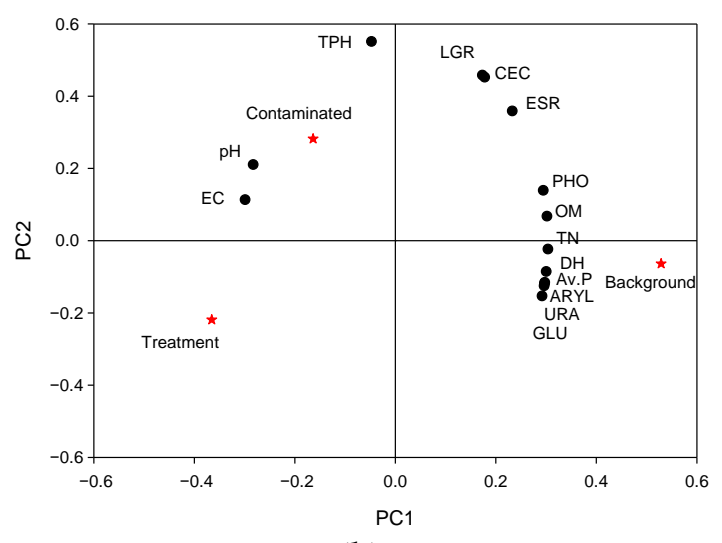

(b)

Figure 3. Principal component analysis (PCA) biplots showing the effect of landfarming and thermal desorption on soil properties: (a) Diesel contaminated, landfarming soil; (b) bunker C contaminated, high-temperature thermal desorption. EC, electrical conductivity; TN, total nitrogen; CEC, cation exchange capacity; Av.P, available phosphours; OM, organic matter; ARYL, arylsulfatase; PHO, alkaline phosphomonoesterase; URA, urease activity; DH, dehydrogenase activity; GLU, B-glucosidase activity; TPH, total petroleum hydrocarbons.

\section{Conclusions}

Changes in various ecological and physicochemical were evaluated in PHC-contaminated soils before and after remediation processes. PHC-contaminated soils can be successfully remediated with LF and HTTD treatments. Although pollution levels were sufficiently lowered, good ecological properties of soil cannot be guaranteed. Compared to the adjacent NCS, ecological properties remained compromised in both treated soils, suggesting that PHC residuals and degradation intermediates can still affect soil health after treatment. Changes in eco-physiochemical properties should be considered to ensure safe soil reuse, and when the goal is to recycle remediated soils. Therefore, monitoring is urgently required to aid accurate estimation of soil ecotoxicity and the effectiveness of bioremediation, while additional soil management methods such as fertilizer application or organic amendments are needed to recover the soil heath. In the case of HTTD, soil ecological properties were severely changed during the remediation process. HTTD is a harsh remediation method that results in deterioration of soil fertility and ecological soil functions; alternatives, such as LTTD, are therefore needed.

Author Contributions: Conceptualization, J.H.L., W.C.J. and M.P.; methodology, M.S.K. and S.J.L.; writing-original draft preparation, S.H.L.; writing-review and editing, H.P. All authors have read and agreed to the published version of the manuscript.

Funding: This research was funded by Korean Environment Industry \& Technology Institute (KEITI) through "Subsurface Environment Management (SEM) Projects", funded by Korea Ministry of Environment (RE202002041).

Conflicts of Interest: The authors declare no conflict of interest. The funders had no role in the design of the study; in the collection, analyses, or interpretation of data; in the writing of the manuscript, or in the decision to publish the results. 


\section{References}

1. Gidarakos, E.; Aivalioti, M. Large scale and longterm application of bioslurping: The case of Greek petroleum refinery site. J. Hazard. Mater. 2007, 149, 574-581. [CrossRef]

2. Iturbe, R.; Flores, C.; Castro, A.; Torres, L.G. Sub-soil contamination due to oil spills in six oil-pipeline pumping station in northern Mexico. Chemosphere 2007, 68, 893-906. [CrossRef]

3. White, P.A.; Claxton, L.D. Mutagens in contaminated soil: A review. Mutat. Res. 2004, 567, $227-345$. [CrossRef]

4. Haaper, P.; Tuhkanen, T. Integrated treatment of PAH contaminated soils by soil washing, Ozonation and biological treatment. J. Hazard. Mater. 2006, B136, 244-250. [CrossRef]

5. Perfumo, A.; Banat, I.M.; Marchant, R.; Vezzulli, L. Thermally enhanced approaches for bioremediation of hydrocarbon-contaminated soils. Chemosphere 2007, 66, 179-184. [CrossRef]

6. Ossai, I.C.; Aziz, A.; Hassan, A.; Hamid, F.S. Remediation of soil and water contaminated with petroleum hydrocarbon: A review. Environ. Technol. Innov. 2020, 17, 100526. [CrossRef]

7. Hou, D.; Al-Tabbaa, A. Sustainability: A new imperative in contaminated land remediation. Environ. Sci. Policy 2014, 39, 25-34. [CrossRef]

8. Jelusic, M.; Grcman, H.; Vodnik, D.; Suhadolc, M.; Lestan, D. Functioning of metal contaminated garden soil after remediation. Environ. Pollut. 2013, 174, 63-70. [CrossRef]

9. Banwart, S. Save our soils. Nature 2011, 474, 151-152. [CrossRef]

10. Sierra, C.; Martínez-Blanco, D.; Blanco, J.A.; Gallego, J.R. Optimization of magnetic separation: A case study for soil washing at a heavy metal polluted site. Chemosphere 2014, 107, 290-296. [CrossRef]

11. Udovic, M.; Lestan, $\mathrm{D}$. Pb, $\mathrm{Zn}$ and $\mathrm{Cd}$ mobility, availability and fractionation in aged soil remediated by EDTA leaching. Chemosphere 2009, 74, 1367-1373. [CrossRef]

12. Villa, R.D.; Trovó, A.G.; Nogueira, R.F.P. Soil remediation using a coupled process: Soil washing with surfactant followed by photo-Fenton oxidation. J. Hazard. Mater. 2010, 174, 770-775. [CrossRef]

13. Tang, X.; He, L.Y.; Dang, Z.; Guo, C.L.; Lu, G.N.; Yi, X.Y. Construction of an artificial microalgal-bacterial consortium that efficiently degrades crude oil. J. Hazard. Mater. 2010, 181, 1158-1162. [CrossRef]

14. Al-Mutairi, N.; Bufarsan, A.; Al-Rukaibi, F. Ecorisk evaluation and treatability potential of soils contaminated with petroleum hydrocarbon-based fuels. Chemosphere 2008, 74, 142-148. [CrossRef]

15. Rao, M.A.; Scelza, R.; Acevedo, F.; Diez, M.C.; Gianfreda, L. Enzymes as useful tools for environmental purposes. Chemosphere 2014, 107, 145-162. [CrossRef]

16. Mremner, J.M. Nitrogen-total. In Method of Soil Analysis: Part III-Chemical Methods; Sparks, D.L., Ed.; American Society of Agronomy: Madison, WI, USA, 1996; pp. 1085-1121.

17. Nelson, D.W.; Sommers, L.E. Total carbon, organic carbon, and organic matter. In Method of Soil Analysis: Part III-Chemical Methods; Sparks, D.L., Ed.; American Society of Agronomy: Madison, WI, USA, 1996; pp. 961-1010.

18. Sumner, M.E.; Miller, W.P. Cation exchange capacity and exchange coefficients. In Method of Soil Analysis: Part III-Chemical Methods; Sparks, D.L., Ed.; American Society of Agronomy: Madison, WI, USA, 1996; pp. 1201-1229.

19. Bray, R.H.; Kurtz, L.T. Determination of total organic and available forms of phosphorus in soils. Soil Sci. 1947, 59, 39-45. [CrossRef]

20. Kemper, W.D.; Rosenau, R.C. Aggregate stability and size distribution. In Methods of Soil Analysis, Part 1. Physical and Mineralogical Methods; Klute, A., Ed.; American Society of Agronomy: Madison, WI, USA, 1986; pp. 425-442.

21. Casida, L.E.; Klein, D.A.; Santoro, T. Soil dehydrogenase activity. Soil Sci. 1964, 98, 371-376. [CrossRef]

22. Eivazi, F.; Tabatabai, M.A. Phosphatases in soil. Soil Biol. Biochem. 1977, 9, 167-172. [CrossRef]

23. Eivazi, F.; Tabatabai, M.A. Glucosidases and galactosidases in soils. Soil Biol. Biochem. 1988, 20, 601-606. [CrossRef]

24. Kandeler, E.; Gerber, H. Short-term assay of soil urease activity using colorimetric determination of ammonium. Biol. Fertil. Soils 1988, 6, 68-72. [CrossRef]

25. Tabatabai, M.A.; Bremner, J.M. Arylsulfatase activity of soils. Soil Sci. Soc. Am. J. 1970, 34, 225-229. [CrossRef] 
26. OECD. Terrestrial plant test: Seedling emergence and seedling growth test. In OECD/OCDE Guidelines for the Testing of Chemical Section 2. Effects on Biotic Systems; Test No. 208.; Organization for Economic and Cooperation Development (OECD): Paris, France, 2006.

27. OECD. Earthworm acute toxicity test. In OECD/OCDE Guidelines for the Testing of Chemical Section 2. Effects on Biotic Systems; Test No. 207.; Organization for Economic and Cooperation Development (OECD): Paris, France, 1984.

28. Jurelevicius, D.; Alvarez, V.M.; Marques, J.M.; Fonseca de Sousa Lima, L.R.; Dias, F.D.A.; Seldin, L. Bacterial community response to petroleum hydrocarbon amendments in freshwater, marine, and hypersaline water-containing microcosms. Appl. Environ. Microbiol. 2013, 79, 5927-5935. [CrossRef]

29. Barcenas-Moreno, G.; Baath, E. Bacterial and fungal growth in soil heated at different temperatures to simulate a range of fire intensities. Soil Biol. Biochem. 2009, 41, 2517-2526. [CrossRef]

30. Guerrero, C.; Mataix-Solera, J.; Gomez, I.; Garcia-Orenes, F.; Jordan, M.M. Microbial recolonization and chemical changes in a soil heated at different temperatures. Int. J. Wildland Fire 2005, 14, 385-400. [CrossRef]

31. Pape, A.; Switzer, C.; McCosh, N.; Knapp, C.W. Impacts of thermal and smouldering remediation on plant growth and soil ecology. Geoderma 2015, 243-244, 1-9. [CrossRef]

32. Wang, J.; Zhan, X.; Zhou, L.; Lin, Y. Biological indicators capable of assessing thermal treatment efficiency of hydrocarbon mixture-contaminated soil. Chemosphere 2010, 80, 837-844. [CrossRef]

33. Xu, J.G.; Johnson, R.L. Root growth, microbial activity and phosphatase activity in oil-contaminated, remediated and uncontaminated soils planted to barley and field pea. Plant Soil 1995, 173, 3-10. [CrossRef]

34. Achuba, F.I. The effect of sublethal concentrations of crude oil on the growth and metabolism of cowpea (Vigna unguiculata) seedlings. Environmentalist 2006, 26, 17-20. [CrossRef]

35. Adam, G.; Duncan, H. Influence of diesel fuel on seed germination. Environ. Pollut. 2002, 120, 363-370. [CrossRef]

36. Douglas, G.S.; Hardenstine, J.H.; Liu, B.; Uhler, A.D. Laboratory and field verification of a method to estimate the extent of petroleum biodegradation in soil. Environ. Sci. Technol. 2012, 46, 8279-8287. [CrossRef]

37. Maqbool, F.; Wang, Z.; JianZho, Y.X.; Gao, D.; Zhao, Y.G. Rhizodegradation of petroleum hydrocarbons by Sesbania cannabina in bioaugmented soil with free and immobilized consortium. J. Hazard. Mater. 2012, 237, 262-269. [CrossRef]

38. Eisentraeger, A.; Hund-Rinke, K.; Roembke, J. Assesment of ecotoxicity of contaminated soil using bioassays. In Manual for Soil Analysis-monitoring and Assessing Soil Bioremediation; Margesin, R., Schinner, F., Eds.; Springer: Berlin, Germany, 2005; pp. 321-359.

39. Shakir Hanna, S.H.; Weaver, R. Earthworm survival in oil contaminated soil. Plant Soil 2002, 240, 127-132. [CrossRef]

40. Ren, J.; Song, X.; Ding, D. Sustainable remediation of diesel-contaminated soil by low temperature thermal treatment: Improved energy efficiency and soil reusability. Chemosphere 2020, 241, 124951. [CrossRef]

Publisher's Note: MDPI stays neutral with regard to jurisdictional claims in published maps and institutional affiliations.

(C) 2020 by the authors. Licensee MDPI, Basel, Switzerland. This article is an open access article distributed under the terms and conditions of the Creative Commons Attribution (CC BY) license (http://creativecommons.org/licenses/by/4.0/). 